\title{
The association between physician trust and prostate-specific antigen screening: Implications for shared decision-making
}

\author{
Zachary Klaassen, MD; Christopher J.D. Wallis, MD; Hanan Goldberg, MD; Thenappan Chandrasekar, MD; \\ Neil E. Fleshner, MD; Antonio Finelli, MD; Girish S. Kulkarni, MD; Allan S. Detsky, MD; Raj Satkunasivam, MD
}

Princess Margaret Cancer Centre, Toronto, ON, Canada

Cite as: Can Urol Assoc J 2018;12(12):395-400. http://dx.doi.org/10.5489/cuaj.5351

Published online June 19, 2018

\begin{abstract}
Introduction: Shared decision-making is widely recommended when men are considering prostate cancer screening with prostatespecific antigen (PSA). The role of patients' trust in cancer information from their physician in such decisions is unknown.

Methods: We identified male respondents $\geq 18$ years of age from the Health Information National Trends Survey, a population-based survey of people living in the U.S. (2011-014). We assessed the association between degree of trust in cancer information from respondent's physician with patient-reported receipt of PSA screening and patient-reported discussion of PSA screening with their physician. Results: Among 5069 eligible respondents, 3606 (71.1\%) men reported trusting cancer information from their physician "a lot," 1186 (23.4\%) "somewhat," 219 (4.3\%) "a little," and 58 (1.1\%) "not at all." A total of 2655 (52.4\%) men reported receiving PSA screening. The degree of trust an individual had in his physician for cancer information was strongly associated with his likelihood of having received PSA screening ( $p_{\text {trend }}<0.0001$ ) (54.9\% "a lot" vs. $27.6 \%$ "not at all"). These findings persisted after multivariable regression. Similarly, men who had high levels of trust in their physician were more likely to have discussed PSA screening with a strong trend across strata $\left(p_{\text {trend }}<0.0001\right)$.

Conclusions: The level of trust an individual has in cancer information from his physician is strongly associated with his likelihood of discussing and undergoing PSA screening. As rationale, implementation of PSA screening requires shared decision-making, and the level of trust an individual has in his physician has important implications for dissemination of PSA screening guidelines.
\end{abstract}

\section{Introduction}

Prostate cancer (PCa) screening using serum prostate-specific antigen (PSA) testing remains controversial. In conflict is level 1 evidence that PSA screening decreases PCa-specific mortality ${ }^{1}$ and the significant risks of overdiagnosis, overtreatment, and treatment-related harms. ${ }^{2}$ Thus, most can- cer organizations recommend that the choice to undergo PSA screening be made through shared decision-making, in which there is a bidirectional sharing of information, followed by consensus regarding the patient's healthcare preferences. ${ }^{3}$ While such an approach offers the opportunity for care that is most aligned with a patient's values, it depends on the rapport between a patient and his physician. Across a variety of healthcare settings, patient and family trust in physicians has been shown to be strongly associated with adoption of shared decision-making. ${ }^{4-6}$ While physicians are an important source of medical information, patients are increasingly using online medical resources to inform their healthcare decisions. ${ }^{7}$

Given the importance of shared decision-making for PSA screening, we sought to assess the association between men's trust in cancer information from their physician and the likelihood of discussing and receiving PSA testing. As a secondary aim, we examined the association between men's trust in cancer information from the internet and these outcomes.

\section{Methods}

\section{Data source}

We used the fourth edition of the Health Information National Trends Survey (HINTS), specifically cycles 1-4 (2011-2014), to identify all men included in the annual national survey. The HINTS database is part of the National Cancer Institute's (NCI) Division of Cancer Control and Population Sciences, collecting national representative data regarding the American public's use of cance-related information. The survey targets adults ( $\geq 18$ years of age) and focuses on how individuals use different communication channels to obtain vital health information. Notably, individuals are not resurveyed, thus data from differing cycles represent unique respondents. For the purposes of this study, the four years of data were manually combined into a single dataset for analysis. We identified 5563 men surveyed from 2011-2014. We excluded 410 for missing data regarding 
receipt or discussion of PSA testing and 84 for missing data regarding their trust in information about cancer from their physician. The data was deidentified by the $\mathrm{NCl}$ prior to being made publicly available, thus institutional review board approval was not required for this study.

\section{Outcomes and covariates}

Our primary outcome was the patient-reported prevalence of PSA screening. The secondary outcome was patient-reported discussions of PSA screening with their physician. The primary exposure was the degree of trust in cancer information from their physician (categorically operationalized as "a lot," "some," "a little," and "not at all"). Secondarily, we assessed the effect of degree of trust in cancer information from the internet (operationalized in the same manner). Other covariates included age (18-34, 35-49, 50-64, 65-74, $\geq 75$ ), race (White, Black, Hispanic, Indian, other), marital status (married, living as married, divorced, widowed, separated, single/never married), geographical region (Northeast, Midwest, South, West), education level (<high school, high school, some college, Bachelor's degree, post-Bac degree), income level (<\$20 000, \$20 000-35 000, \$35 000-50 000, $\$ 50$ 000-<75 000, >\$75 000), health insurance (yes/no), born in the U.S. (yes/no), self-assessment of general health (excellent, very good, good, fair, poor), smoking status (current, former, never), and Patient Health Questionnaire-4 score (PHQ-4; an assessment of psychological distress ${ }^{8}$ ).

\section{Statistical analyses}

We used the Cochran-Armitage test to identify significant trends for each outcome across the levels of trust. Subsequently, a multivariable logistic regression model assessed the association between trust in information from physicians and from the internet and each outcome, adjusting for the above covariates (selected a priori). The American Urological Association (AUA) recommends shared decision-making for men 55-69 years of age, based on benefits of PSA screening outweighing harms. ${ }^{9}$ As such, a sensitivity analysis using the above models was performed only for men 55-69 years of age to assess the impact of the aforementioned exposure variable and covariates on PSA screening in this target group. Goodness of fit and multicollinearity were assessed for each model, with no evidence of violations. Statistical analyses were performed using SAS 9.4 (SAS Institute, Cary, NC, U.S.). All tests were two-sided, with statistical significance set at $\mathrm{p}<0.05$.

\section{Results}

Among 5069 eligible respondents, 3606 (71.1\%) men reported trusting cancer information from their physician "a lot," 1186 (23.4\%) "some," 219 (4.3\%) "a little," and 58 $(1.1 \%)$ "not at all." White, married men with higher levels of education and income were more likely to report a higher degree of trust in their physician (Table 1). Furthermore, patients with high levels of trust in their physician tended to have health insurance, be born in the U.S., and report no psychological distress. There were 767 men (15.1\%) that reported "a lot" of trust in cancer information from the internet, 2543 (50.2\%) "some," 1044 (20.6\%) "a little," 448 $(8.8 \%)$ "not at all," and 267 (5.3\%) didn't answer the question. There was weak correlation between an individual's trust in information from physicians and information from the internet (Pearson correlation coefficient 0.078, 95\% confidence interval [CI] 0.039-0.118) (Supplementary Table 1).

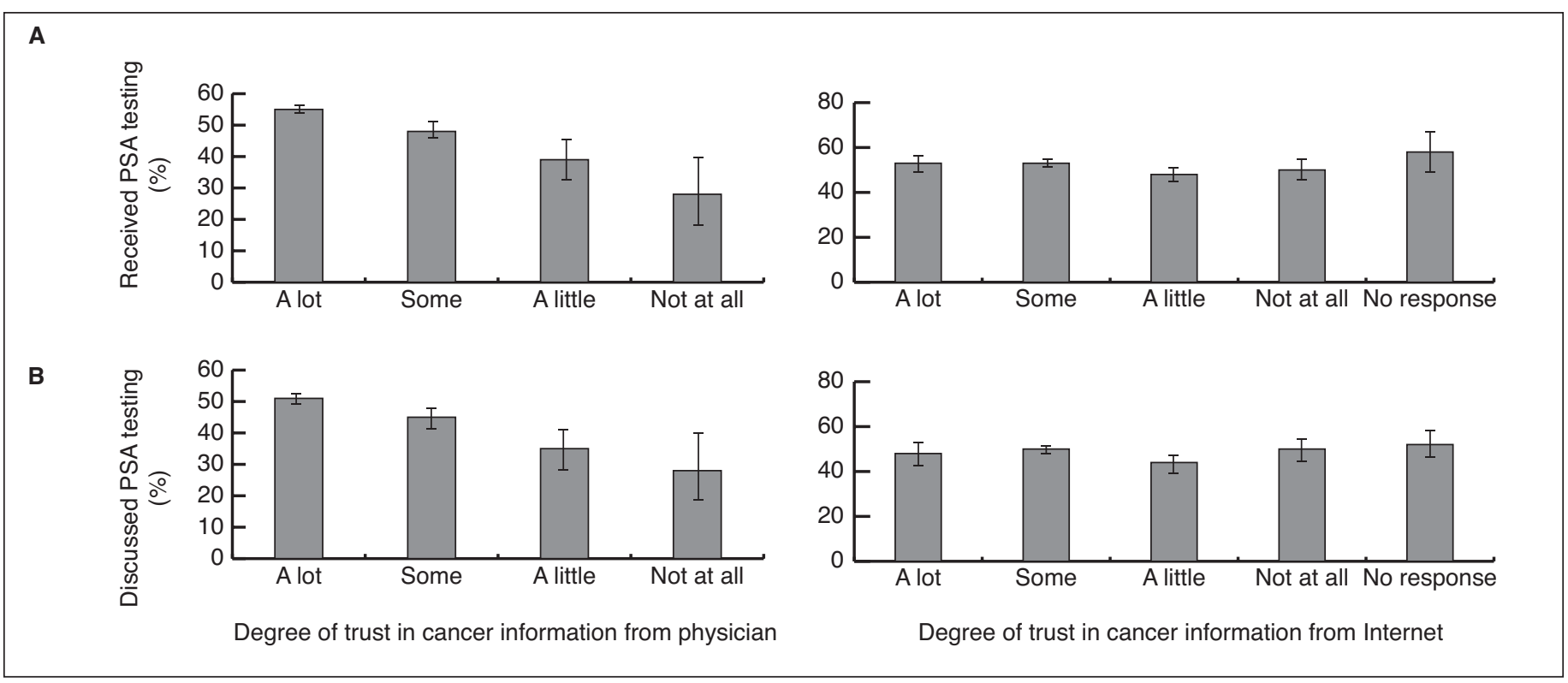

Fig. 1. Proportion of respondents reporting (A) receiving a prostate-specific antigen (PSA) test; and (B) discussing PSA screening with their physician. 
Patient trust in cancer information from physician

\begin{tabular}{|c|c|c|c|}
\hline \multirow[b]{2}{*}{ Variables } & \multicolumn{2}{|c|}{$\begin{array}{l}\text { Level of trust about cancer } \\
\text { information from physician }\end{array}$} & \multirow[b]{2}{*}{$\mathbf{p}$} \\
\hline & A lot & $\begin{array}{c}\text { Some/a little/ } \\
\text { not at all }\end{array}$ & \\
\hline Sample size & 3606 & 1463 & \\
\hline Age & & & 0.0002 \\
\hline $18-34$ & $440(12.2)$ & $131(9.0)$ & \\
\hline $35-49$ & 735 (20.4) & $347(23.7)$ & \\
\hline $50-64$ & $1,274(35.3)$ & $524(35.8)$ & \\
\hline $65-75$ & $672(18.6)$ & $244(16.7)$ & \\
\hline$\geq 75$ & $418(11.6)$ & $173(11.8)$ & \\
\hline Unknown & $67(1.9)$ & $44(3.0)$ & \\
\hline Race & & & $<0.0001$ \\
\hline White & 2,391 (66.3) & $871(59.5)$ & \\
\hline Black & $440(12.2)$ & $184(12.6)$ & \\
\hline Hispanic & $115(3.2)$ & $75(5.1)$ & \\
\hline Indian & $19(0.5)$ & $10(0.7)$ & \\
\hline Other & $188(5.2)$ & $100(6.8)$ & \\
\hline Unknown & $453(12.6)$ & $223(15.2)$ & \\
\hline Marital status & & & $<0.0001$ \\
\hline Married & $2,129(59.0)$ & $794(54.3)$ & \\
\hline Living as married & $113(3.1)$ & $56(3.8)$ & \\
\hline Divorced & $449(12.5)$ & $224(15.3)$ & \\
\hline Widowed & $165(4.6)$ & $86(5.9)$ & \\
\hline Separated & $77(2.1)$ & $44(3.0)$ & \\
\hline Single/never married & 607 (16.8) & $214(14.6)$ & \\
\hline Unknown & $66(1.8)$ & $45(3.1)$ & \\
\hline Geographical region & & & 0.45 \\
\hline Northeast & $575(16.0)$ & $220(15.0)$ & \\
\hline Midwest & 705 (19.6) & $268(18.3)$ & \\
\hline South & $1465(40.6)$ & $601(41.1)$ & \\
\hline West & 861 (23.9) & $374(25.6)$ & \\
\hline Education level & & & $<0.0001$ \\
\hline$<$ High school & $283(7.9)$ & $146(10.0)$ & \\
\hline High school & $649(18.0)$ & $308(21.1)$ & \\
\hline Some college & $1059(29.4)$ & 477 (32.6) & \\
\hline Bachelor's degree & $906(25.1)$ & $293(20.0)$ & \\
\hline Post-bac degree & $659(18.3)$ & $198(13.5)$ & \\
\hline Unknown & $50(1.4)$ & $41(2.8)$ & \\
\hline Income level & & & $<0.0001$ \\
\hline$<\$ 20000$ & $475(13.2)$ & $286(19.6)$ & \\
\hline$\$ 20000-35000$ & $463(12.8)$ & $212(14.5)$ & \\
\hline$\$ 35000-50000$ & $484(13.4)$ & $173(11.8)$ & \\
\hline$\$ 50000-<75000$ & $624(17.3)$ & $229(15.7)$ & \\
\hline$>\$ 75000$ & 1217 (33.8) & $396(27.1)$ & \\
\hline Unknown & 343 (9.5) & $167(11.4)$ & \\
\hline
\end{tabular}

Among the 5069 eligible men, 2655 (52.4\%) men received PSA screening. The degree of trust an individual had in cancer information from his physician was strongly associated with

\begin{tabular}{|c|c|c|c|}
\hline \multirow[b]{2}{*}{ Variables } & \multicolumn{2}{|c|}{$\begin{array}{l}\text { Level of trust about cancer } \\
\text { information from physician }\end{array}$} & \multirow[b]{2}{*}{$\mathbf{p}$} \\
\hline & A lot & $\begin{array}{c}\text { Some/a little/ } \\
\text { not at all }\end{array}$ & \\
\hline Health insurance & & & $<0.0001$ \\
\hline Yes & $2271(75.5)$ & $1010(69.0)$ & \\
\hline No & 840 (23.3) & $429(29.3)$ & \\
\hline Unknown & $45(1.3)$ & $24(1.6)$ & \\
\hline Born in U.S. & & & $<0.0001$ \\
\hline Yes & $3088(85.6)$ & $1180(80.7)$ & \\
\hline No & 485 (13.5) & $254(17.4)$ & \\
\hline Unknown & $33(0.9)$ & $29(2.0)$ & \\
\hline $\begin{array}{l}\text { Self-assessment of } \\
\text { general health }\end{array}$ & & & $<0.0001$ \\
\hline Excellent & 424 (11.8) & $126(8.6)$ & \\
\hline Very good & 1368 (37.9) & $463(31.7)$ & \\
\hline Good & $1264(35.1)$ & $565(38.6)$ & \\
\hline Fair & $376(10.4)$ & $221(15.1)$ & \\
\hline Poor & $100(2.8)$ & $53(3.6)$ & \\
\hline Unknown & $74(2.1)$ & $35(2.4)$ & \\
\hline Smoking status & & & 0.007 \\
\hline Current & $554(15.4)$ & $275(18.8)$ & \\
\hline Former & $1194(33.1)$ & $430(29.4)$ & \\
\hline Never & $1827(50.7)$ & $747(51.1)$ & \\
\hline Unknown & $31(0.9)$ & $11(0.8)$ & \\
\hline PHO-4* & & & $<0.0001$ \\
\hline None & $2,048(75.4)$ & $693(64.7)$ & \\
\hline Mild & $414(15.2)$ & $215(20.1)$ & \\
\hline Moderate & $146(5.4)$ & $109(10.2)$ & \\
\hline Severe & $109(4.0)$ & $54(5.0)$ & \\
\hline $\begin{array}{l}\text { Level of trust about } \\
\text { cancer information from } \\
\text { internet }\end{array}$ & & & $<0.0001$ \\
\hline A lot & 625 (17.3) & $142(9.7)$ & \\
\hline
\end{tabular}

his likelihood of receiving PSA screening: $54.9 \%$ of men who reported "a lot" of trust underwent screening, 48.6\% who reported "some" trust, 38.4\% who reported "a little" trust, and $27.6 \%$ who reported "not at all" trusting their physician $\left(p_{\text {trend }}<0.0001\right)$ (Fig. 1A). The degree to which an individual trusted cancer information from the internet was also associated with having received PSA screening $(p=0.005)$, albeit with an insignificant trend ( $p=0.07$ ) (Fig. 1A). After multivariable adjustment, these significant results persisted only for degree of trust in information from the physician (Table 2). As patients may also seek health advice from family and friends, we assessed the association between trust in these data sources and receipt of PSA screening. We found no significant association $(\mathrm{p}=0.28)$ and inclusion of this variable didn't modify the effect of trust in physician. 
Klaassen et al

\begin{tabular}{|c|c|c|c|c|}
\hline \multirow[b]{2}{*}{ Variables } & \multicolumn{2}{|c|}{ Receiving PSA testing } & \multicolumn{2}{|c|}{ Discussing PSA screening } \\
\hline & OR (95\%Cl) & p & OR (95\%Cl) & p \\
\hline \multicolumn{5}{|c|}{ Level of trust about cancer information from physician } \\
\hline \multicolumn{5}{|l|}{ Marital status } \\
\hline Married & Ref & & Ref & \\
\hline Living as married & $1.08(0.68-1.72)$ & 0.75 & $1.14(0.73-1.77)$ & 0.57 \\
\hline Divorced & $0.89(0.70-1.13)$ & 0.33 & $0.88(0.70-1.11)$ & 0.28 \\
\hline Widowed & $0.82(0.55-1.23)$ & 0.34 & $0.88(0.61-1.29)$ & 0.52 \\
\hline Separated & $0.66(0.40-1.11)$ & 0.11 & $1.01(0.62-1.67)$ & 0.96 \\
\hline Never married & $0.63(0.49-0.82)$ & $<0.001$ & $0.62(0.48-0.79)$ & $<0.001$ \\
\hline \multicolumn{5}{|l|}{ Geographical region } \\
\hline Northeast & Ref & & Ref & \\
\hline Midwest & $0.89(0.68-1.18)$ & 0.42 & $0.91(0.70-1.18)$ & 0.47 \\
\hline South & $1.14(0.90-1.45)$ & 0.29 & $1.09(0.87-1.37)$ & 0.45 \\
\hline West & $0.83(0.64-1.08)$ & 0.16 & $0.85(0.66-1.09)$ & 0.20 \\
\hline \multicolumn{5}{|l|}{ Education level } \\
\hline$<$ High school & Ref & & Ref & \\
\hline High school & $1.30(0.93-1.82)$ & 0.13 & $1.11(0.80-1.54)$ & 0.53 \\
\hline Some college & $1.70(1.22-2.35)$ & 0.002 & $1.34(0.98-1.84)$ & 0.07 \\
\hline Bachelor's degree & $2.30(1.62-3.27)$ & $<0.001$ & $1.54(1.10-2.16)$ & 0.01 \\
\hline Post-bac degree & $3.30(2.25-4.83)$ & $<0.001$ & $2.07(1.44-2.97)$ & $<0.001$ \\
\hline \multicolumn{5}{|l|}{ Income level } \\
\hline$<\$ 20000$ & Ref & & Ref & \\
\hline$\$ 20000-35000$ & $1.42(1.05-1.93)$ & 0.02 & $1.36(1.01-1.82)$ & 0.04 \\
\hline$\$ 35000-50000$ & $1.45(1.06-1.99)$ & 0.02 & $1.29(0.96-1.75)$ & 0.09 \\
\hline$\$ 50000-75000$ & $1.53(1.12-2.08)$ & 0.007 & $1.39(1.03-1.87)$ & 0.03 \\
\hline$>\$ 75000$ & $1.56(1.15-2.11)$ & 0.004 & $1.49(1.11-1.99)$ & 0.007 \\
\hline \multicolumn{5}{|l|}{ Health insurance } \\
\hline Yes & Ref & & Ref & \\
\hline No & $0.80(0.65-0.98)$ & 0.03 & $0.86(0.71-1.05)$ & 0.15 \\
\hline \multicolumn{5}{|l|}{ Born in U.S. } \\
\hline Yes & Ref & & Ref & \\
\hline No & $0.65(0.49-0.85)$ & 0.002 & $0.69(0.53-0.90)$ & 0.006 \\
\hline \multicolumn{5}{|c|}{ Self-assessment of general health } \\
\hline Excellent & Ref & & Ref & \\
\hline Very good & $1.12(0.84-1.48)$ & 0.44 & $1.01(0.77-1.31)$ & 0.97 \\
\hline Good & $1.11(0.84-1.48)$ & 0.46 & $0.95(0.72-1.25)$ & 0.72 \\
\hline Fair & $0.95(0.67-1.35)$ & 0.77 & $0.90(0.64-1.25)$ & 0.52 \\
\hline Poor & $1.18(0.69-2.02)$ & 0.54 & $0.93(0.55-1.55)$ & 0.77 \\
\hline \multicolumn{5}{|l|}{ Smoking status } \\
\hline Current & Ref & & Ref & \\
\hline Former & $1.48(1.15-1.90)$ & 0.002 & $1.27(1.00-1.62)$ & 0.054 \\
\hline Never & $1.32(1.04-1.67)$ & 0.02 & $1.36(1.08-1.71)$ & 0.009 \\
\hline \multicolumn{5}{|l|}{ PHQ-4 } \\
\hline None & Ref & & Ref & \\
\hline Mild & $0.96(0.77-1.20)$ & 0.74 & $0.86(0.70-1.06)$ & 0.16 \\
\hline Moderate & $1.05(0.75-1.46)$ & 0.79 & $0.90(0.65-1.23)$ & 0.50 \\
\hline Severe & $0.79(0.52-1.20)$ & 0.26 & $0.71(0.47-1.08)$ & 0.11 \\
\hline
\end{tabular}




\begin{tabular}{|c|c|c|c|}
\hline Variables & OR & $95 \% \mathrm{Cl}$ & $\mathbf{p}$ \\
\hline \multicolumn{4}{|c|}{ Model 1 - Receipt of PSA test } \\
\hline \multicolumn{4}{|c|}{ Level of trust about cancer information from physician } \\
\hline A lot & Ref & Ref & \\
\hline Some & 0.77 & $0.57-1.04$ & 0.09 \\
\hline A little & 0.58 & $0.31-1.09$ & 0.09 \\
\hline Not at all & 0.26 & $0.08-0.90$ & 0.03 \\
\hline \multicolumn{4}{|c|}{ Level of trust about cancer information from internet } \\
\hline A lot & Ref & Ref & \\
\hline Some & 1.23 & $0.86-1.76$ & 0.26 \\
\hline A little & 0.95 & $0.62-1.44$ & 0.80 \\
\hline Not at all & 0.61 & $0.36-1.05$ & 0.07 \\
\hline \multicolumn{4}{|l|}{ Marital status } \\
\hline Married & Ref & Ref & \\
\hline Divorced & 0.68 & $0.48-0.97$ & 0.03 \\
\hline $\begin{array}{l}\text { Single/never } \\
\text { married }\end{array}$ & 0.56 & $0.37-0.85$ & 0.007 \\
\hline \multicolumn{4}{|l|}{ Education level } \\
\hline$<$ High school & Ref & Ref & \\
\hline Bachelor's degree & 1.87 & $1.07-3.28$ & 0.03 \\
\hline Post-bac degree & 3.42 & $1.80-6.49$ & 0.0002 \\
\hline \multicolumn{4}{|l|}{ Income level } \\
\hline$<\$ 20000$ & Ref & Ref & \\
\hline$\$ 50000-<75000$ & 1.85 & $1.12-3.05$ & 0.02 \\
\hline \multicolumn{4}{|l|}{ Born in U.S. } \\
\hline Yes & Ref & Ref & \\
\hline No & 0.57 & $0.36-0.92$ & 0.02 \\
\hline \multicolumn{4}{|l|}{ Smoking status } \\
\hline Current & Ref & Ref & \\
\hline Former & 1.89 & $1.31-2.73$ & 0.0006 \\
\hline Never & 1.59 & $1.11-2.27$ & 0.01 \\
\hline \multicolumn{4}{|c|}{ Model 2 - Discussed PSA screening } \\
\hline \multicolumn{4}{|c|}{ Level of trust about cancer information from physician } \\
\hline A lot & Ref & Ref & \\
\hline Some & 0.76 & $0.58-1.01$ & 0.06 \\
\hline A little & 0.56 & $0.31-1.04$ & 0.07 \\
\hline Not at all & 0.44 & $0.14-1.36$ & 0.15 \\
\hline \multicolumn{4}{|c|}{ Level of trust about cancer information from internet } \\
\hline A lot & Ref & Ref & \\
\hline Some & 1.07 & $0.77-1.48$ & 0.69 \\
\hline A little & 0.98 & $0.67-1.45$ & 0.93 \\
\hline Not at all & 0.65 & $0.39-1.08$ & 0.10 \\
\hline \multicolumn{4}{|l|}{ Education level } \\
\hline$<$ High school & Ref & Ref & \\
\hline Post-bac degree & 2.47 & $1.39-4.42$ & 0.002 \\
\hline \multicolumn{4}{|l|}{ Income level } \\
\hline$<\$ 20000$ & Ref & Ref & \\
\hline$\$ 50000-<75000$ & 1.97 & $1.23-3.14$ & 0.005 \\
\hline \multicolumn{4}{|c|}{$\begin{array}{l}\text { *All models adjusted for race, marital status, geographical region, education level, income } \\
\text { level, health insurance, born in the USA, self-assessment of general health, smoking status } \\
\text { PHQ-4, level of trust about cancer information from the internet, level of trust about cancer } \\
\text { information from physician. Cl: confidence interval; OR: odds ratio; PSA: prostate-specific } \\
\text { antigen; Ref: reference. }\end{array}$} \\
\hline
\end{tabular}

There were $2472(48.8 \%)$ men who discussed PSA screening with their physician. Men who had high levels of trust in their physician were more likely to have discussed PSA screening $(p<0.0001)$, with a strong trend across strata $(p<0.0001)$ (Fig. 1B). Results from multivariable models recapitulated these findings (Table 2).

As the AUA explicitly recommends shared decisionmaking for men 55-69 years of age, ${ }^{9}$ we performed a preplanned sensitivity analysis among the 1826 men in this age bracket. There were 1293 (70.8\%) men who reported undergoing PSA screening and 1173 (64.2\%) had discussed PSA screening with their physician. Patients who did not trust their physician at all regarding cancer information were significantly less likely to receive PSA testing (vs. "a lot": odds ratio [OR] 0.26; 95\% Cl 0.08-0.90) (Table 3). Level of trust regarding cancer information from the patient's physician did not impact discussions regarding PSA screening.

\section{Discussion}

Using a large, nationally representative survey, the level of trust an individual has in cancer information from his physician was one of the strongest predictors of discussing and receiving PSA screening. In fact, only age was a stronger predictor of receiving PSA screening among data collected in this survey. While trust has been previously associated with shared decision-making, this study provides uniquely generalizable results. Interestingly, previous work has shown that individuals with high, but not excessive, levels of trust are most likely to engage in shared decision-making. ${ }^{5}$ Patients with very high levels of trust may blindly defer to their physicians, while those with very low levels may opt for autonomous roles. ${ }^{5}$ Given that this survey is disseminated nationally across the U.S., with broad inclusion criteria ( $\geq 18$ years of age), we feel that these findings are likely generalizable to most first-world, multicultural countries, including Canada.

It is perhaps intuitive that a man who trusts his physician is more likely to undergo PSA screening based on the physician's recommendation. One may infer that primary care physicians are strongly recommending PSA screening. However, it is not immediately apparent that this is true. ${ }^{10}$ Alternatively, men may receive balanced information and decide to undergo testing based on a desire to avoid potential loss due to underdiagnosis, in keeping with prospect theory. ${ }^{11}$ Finally, it is possible that men who trust their physician may place more trust in the healthcare system in general and thus engage in PSA screening based on this principle.

Our study found several noteworthy findings with regards to the impact of race and socioeconomic status on the effect of receiving and/or discussing PSA screening. First, and importantly, minority populations (i.e., Black, Hispanic, etc.) were just as likely to receive or discuss PSA screening with their physician as White individuals. Historically, 
minorities have been less likely and perhaps less willing to undergo PSA testing. ${ }^{12,13}$ Several perceived and actual barriers include a lack of: health insurance, knowledge, a sense of urgency, and recommendation for routine screening from primary care providers. ${ }^{14}$ Second, we found an effect gradient of greater odds of receiving or discussing PSA screening with increasing income and education level. These results are consistent with previous studies that suggest men with higher income and those who are more educated are more likely to undergo PSA testing. ${ }^{15-17}$

Due to the nature of the data source, there are intrinsic limitations. First, recall bias is a risk in any cross-sectional survey, although it is not clear that this would exert a differential effect. Second, although the HINTS database accounts for many factors that may influence PCa screening, other factors, including family history and voiding symptoms, are not captured. Third, the nature of the physician counselling involved in shared decision-making is unknown. Thus, physicians may be either encouraging or discouraging PSA screening. Fourth, the HINTS database does not have laboratory values, thus there is no way to ascertain whether a participant truly underwent PSA testing. Fifth, we were unable to compare PCa screening to other cancers or conditions (i.e., HIV), as these were not captured in the survey. Sixth, the racial demographics of participants included in the HINTS database may not accurately reflect those of the U.S. population as a whole. Finally, this study may represent reverse causality, with patients having increased trust in physicians that discuss PSA testing or explicitly offer it.

\section{Conclusion}

The level of trust a man has in cancer information from his physician is strongly associated with his likelihood of discussing and undergoing PSA screening. As rational implementation of PSA screening requires shared decision-making, the level of trust an individual has in his physician has important implications for dissemination of PSA screening guidelines.

Competing interests: Dr. Finelli has been a consultant for AbbVie, Amgen, Astellas, Ferring, HoffmanLaRoche, Ipsen, Janssen, Sanofi, and Tesaro; and has participated in clinical trials supported by AstraZeneca, Hybridine, and Medivation. The remaining authors report no competing personal or financial interests.

This paper has been peer-reviewed.

\section{References}

1. Schroder FH, Hugosson J, Roobol MJ, et al. Screening and prostate-cancer mortality in a randomized European study. N Engl J Med 2009;360:1320-8. https://doi.org/10.1056/NEJMoo0810084
2. Moyer VA, Force USPST. Screening for prostate cancer: U.S. Preventive Services Task Force recommendation statement. Ann Intern Med 2012;157:120-34. https://doi.org/10.7326/0003-4819-157-2201207170-00459

3. Charles C, Gafni A, Whelan T. Shared decision-making in the medical encounter: What does it mean? (or it takes at least two to tango). Soc Sci Med 1997;44:681-92. https://doi.org/10.1016/S02779536(96)00221-3

4. Peek ME, Gorawara-Bhat R, Quinn MT, et al. Patient trust in physicians and shared decision-making among African-Americans with diabetes. Health Commun 2013;28:616-23. hitps://doi.org/10.108 0/10410236.2012.710873

5. Kraetschmer N, Sharpe N, Urowitz $\mathrm{S}$, et al. How does trust affect patient preferences for participation in decision-making? Health Expect 2004;7:317-26. https://doi.org/10.1111/i.1369-7625.2004.00296.x

6. Epstein $\mathrm{EG}$, Wolfe K. A preliminary evaluation of trust and shared decision-making among intensive care patients' family members. Appl Nurs Res 2016;32:286-8. https://doi.org/10.1016/i. apnr.2016.08.011

7. Diaz JA, Griffith RA, Ng JJ, et al. Patients' use of the internet for medical information. J Gen Intern Med 2002:17:180-5. https://doi.org/10.1046/i.1525-1497.2002.10603.x

8. Kroenke K, Spitzer RL, Williams JB, et al. An ultra-brief screening scale for anxiety and depression: The PHQ-4. Psychosomatics 2009;50:613-21.

9. Carter HB, Albertsen PC, Barry MJ, et al. Early detection of prostate cancer: AUA guideline. J Urol 2013;190:419-26. https://doi.org/10.1016/i.juro.2013.04.119

10. Miller A, Yates J, Epstein MM, et al. Impact of 2012 USPSTF screening PSA guideline statement: Changes in primary care provider practice patterns and attitudes. Urology Practice 2017;4:126-31. https://doi.org/10.1016/i.urpr.2016.04.003

11. Verma AA, Razak F, Detsky AS. Understanding choice: Why physicians should learn prospect theory. JAMA 2014;311:571-2. hitps://doi.org/10.1001/jama.2013.285245

12. Dean LT, Subramanian SV, Williams DR, et al. Getting Black men to undergo prostate cancer screening: The role of social capital. Am J Mens Health 2015;9:385-96. hitps://doi.org/10.1177/1557988314546491

13. Gorday W, Sadrzadeh H, de Koning L, et al. Association of sociodemographic factors and prostatespecific antigen (PSA) testing. Clin Biochem 2014;47:164-9. https://doi.org/10.1016/i.linbiochem.2014.08.006

14. Weinrich SP, Reynolds WA Jr, Tingen MS, et al. Barriers to prostate cancer screening. Cancer Nurs 2000;23:117-21. https://doi.org/10.1097/00002820-200004000-00007

15. Burns R, Walsh $B, 0^{\prime}$ Neill $S$, et al. An examination of variations in the uptake of prostate cancer screening within and between the countries of the EU-27. Health Policy 2012;108:268-76. https://doi.org/10.1016/i.healthpol.2012.08.014

16. Bowen DJ, Hannon PA, Harris JR, et al. Prostate cancer screening and informed decision-making: Provider and patient perspectives. Prostate Cancer Prostatic Dis 2011;14:155-61. https://doi.org/10.1038/ pcan. 2010.55

17. Steenland K, Rodriguez C, Mondul A, et al. Prostate cancer incidence and survival in relation to education (United States). Cancer Causes Control 2004;15:939-45. htrps://doi.org/10.1007/s10552-0042231-5

Correspondence: Dr. Zachary Klaassen, Princess Margaret Cancer Centre, Toronto, ON, Canada; zklaassen19@gmail.com

\begin{tabular}{|c|c|c|c|c|}
\hline \multicolumn{5}{|c|}{$\begin{array}{l}\text { Supplementary Table } 1 \text {. Correlation between an } \\
\text { individual's expressed trust in cancer information } \\
\text { from their physician and from the internet }(\mathrm{n}=5069) \text {. A } \\
\text { significant, but weak association was observed (Pearson } \\
\text { correlation coefficient }=0.078 ; 95 \% \mathrm{Cl} 0.039-0.118 \text { ) }\end{array}$} \\
\hline \multirow[t]{2}{*}{$\begin{array}{l}\text { Degree of trust in cancer } \\
\text { information from the internet }\end{array}$} & \multicolumn{4}{|c|}{$\begin{array}{l}\text { Degree of trust in cancer } \\
\text { information from physician }\end{array}$} \\
\hline & A lot & Some & A little & Not at all \\
\hline A lot & 625 & 111 & 23 & 8 \\
\hline Some & 1863 & 606 & 67 & 7 \\
\hline A little & 653 & 304 & 81 & 6 \\
\hline Not at all & 285 & 117 & 29 & 17 \\
\hline Unknown & 180 & 48 & 19 & 20 \\
\hline
\end{tabular}

